\title{
Influenzához kapcsolódó halálozás 2009/2010 és 2016/2017 között Magyarországon
}

\author{
Kovács Katalin ${ }^{1,2}$ - Pakot Levente ${ }^{1}$ \\ ${ }^{1}$ Központi Statisztikai Hivatal, Népességtudományi Kutatóintézet, Budapest \\ ${ }^{2}$ Semmelweis Egyetem, Magatartástudományi Intézet, Budapest
}

Bevezetés: Magyarországon az elmúlt években több alkalommal is tapasztaltunk az év első három hónapjában halálozási csúcsokat. Az influenza szerepének tisztázására még nem született olyan halandósági elemzés, amelynek eredményei más országok ugyanolyan módszerrel kapott eredményeivel összehasonlíthatók lennének.

Célkitüzés: A 2009/10 és 2016/17 közötti időszakra vonatkozóan az influenzához köthető magyarországi többlethalálozások alakulásának bemutatása a FluMOMO statisztikai programcsomag alkalmazásával.

Módszer: A halálozások heti számát (függő változó) modellezzük egy többváltozós idősoros elemzéssel, amelyben az influenzaaktivitás és az extrém időjárási körülmények szerepelnek magyarázó változóként. Az influenzaaktivitást az influenzaszerű tünetekkel háziorvoshoz fordulók konzultációs aránya (ILI) alapján becsüljük.

Eredmények: Az influenzával összefüggésbe hozhatóan 2009/10-ben 1091, 2010/11-ben 2969, 2011/12-ben 4036, 2012/13-ban 2336, 2013/14-ben 2608, 2014/15-ben 6470, 2015/16-ban 51, 2016/17-ben pedig 5162 haláleset történhetett. Az évenkénti átlagos többlethalandósági ráta az össznépességben 0,5 és 52,7 ( $1 / 100$ 000) fó között alakult. A halálozás más országokban hasonló módszerrel kapott számokhoz és rátákhoz viszonyítva Magyarországon hasonló nagyságrendű, ugyanakkor tendenciaszerúen magasabb.

Következtetés: Magasabb oltási arányt elért országokban az influenza okozta halálozás tendenciaszerüen alacsonyabb; Magyarországon az oltási ráta növelésére van szükség.

Orv Hetil. 2020; 161(23): 962-970.

Kulcsszavak: FluMOMO, influenza, halandóság, szezonalitás, vakcináció

\section{Influenza-associated mortality in Hungary between 2009/2010 and 2016/2017}

Introduction: In recent years, a significant mortality peak has been observed several times during the first months in Hungary. So far, no mortality study clarified the connection between the mortality peaks and influenza with results comparable with findings from other countries.

Aim: Calculation of the influenza-related number of death and excess mortality rates in Hungary for the period between 2009/10 and 2016/17, using the statistical package FluMONO.

Method: We applied the FluMOMO methods, a multivariable time series model with all-cause mortality as outcome, and with influenza-activity and extreme temperature as explanatory variables adjusting for time trend and seasonality. As an indicator of weekly influenza-activity (IA), we used the percentage of consultations for influenza-like illness (ILI) in general practices.

Results: According to our estimation, 1091, 2969, 4036, 2336, 2608, 6470, 51 and 5162 deaths were attributable to influenza epidemics in the $2009 / 10,2010 / 11,2011 / 12,2012 / 13,2013 / 14,2014 / 15,2015 / 16$ and $2016 / 17$ seasons, respectively. The average annual mortality excess rate per 100,000 inhabitants ranged between 0.5 and 52.7 . These results are similar to those from other countries regarding their order of magnitude. The Hungarian extra mortality, however, tends to be higher than that in countries with higher vaccination rates.

Conclusions: Influenza-related mortality tends to be lower in countries with higher vaccination rates. Increase in vaccination rates seems to be necessary in Hungary.

Keywords: FluMOMO, influenza, mortality, vaccination

Kovács K, Pakot L. [Influenza-associated mortality in Hungary between 2009/2010 and 2016/2017]. Orv Hetil. 2020; 161(23): 962-970.

(Beérkezett: 2020. január 9.; elfogadva: 2020. február 20.) 


\section{Rövidítések}

ÁNTSZ = Állami Népegészségügyi és Tisztiorvosi Szolgálat; $\mathrm{BNO}=$ betegségek nemzetközi osztályozása; $\mathrm{ET}=($ extreme temperature) extrém hőmérséklet; EuroMOMO = (European mortality monitoring) európai halálozási megfigyelés; FluMOMO = (flu mortality monitoring) influenzahalálozási megfigyelés; IA = (influenza activity) influenzaaktivitás; ILI = (influenza-like illness) influenzaszerú betegség; NOAA = (National Oceanic and Atmospheric Administration) Nemzeti Óceán- és Légkörkutatási Hivatal; OECD $=($ Organisation for Economic Co-operation and Development) Gazdasági Együttmúködési és Fejlesztési Szervezet; WHO = (World Health Organization) Egészségügyi Világszervezet

Két évvel ezelőtt, a világszerte 50-100 millióra becsült áldozattal járó spanyolnáthajárvány 100. évfordulóján a kutatók megújuló figyelemmel fordultak az influenza kérdése felé [1]. Történeti demográfusok sora próbálja megfejteni a 100 évvel ezelőtti járvány részleteit, és kutatásaik egy része a jelen számára is üzen $[2,3]$. Magyarországon például, ahol a történeti adatok tanúsága szerint európai összehasonlításban magas volt a spanyolnáthához kapcsolódó halálozás a civil lakosság körében [4], az időszak viharos történelmi eseményei elterelték róla a figyelmet. Hasonlónak tûnik a helyzet napjainkban is: míg sok más országban az influenza ma is élénk szakmai és társadalmi diskurzus tárgya, Magyarországon kevés szó esik róla.

Magyarországon 2017-ben, illetve azt megelőzően 2015-ben is jelentősen megnövekedtek a téli-kora tavaszi halálozási esetszámok. Többen feltételezték, hogy ennek hátterében a szokásosnál erôsebb influenzajárványok hatása állhat [5], de módszertani szempontból kielégítő elemzésre, különösképpen pedig a magyarországi, influenza okozta halálozási többlet más országok hasonló adataival való összevetésére még nem került sor. 2018 tavaszán a WHO által megbízott statisztikusi munkacsoport közzétett egy, az influenzával kapcsolatba hozható halálozások becslésére alkalmas programcsomagot, ezenfelül az ennek a programcsomagnak az alkalmazásával készített, Dániára vonatkozó becsléseit is publikálta [6]. Cikkünkben a fent említett programcsomag magyarországi adatokra való alkalmazásának eredményeit kívánjuk bemutatni, azaz az influenzához köthető többlethalálozás alakulását a 2009/10 és 2016/17 közötti időszakban.

\section{Módszer}

\section{Az influenzához kapcsolódó halálozás becslésének módszertani kérdései}

Az influenza elkülönült halálok, a BNO X. verziójában a J10-es és J1 l-es tételek alatt szerepel. Történeti érdekességként megjegyezzük, hogy az influenzát már az 1918ban használatos haláloki klasszifikációban is önálló halálokként szerepeltették: az influenzaként besorolt halálo- zások száma (amely 1908 és 1947 között évi 313 és 1241 között ingadozott) 1918-ban 53201 volt. Már az akkori klasszifikáció szerint közölt adatokban is feltűnő, hogy 1918-ban az influenzán kívül a tüdő- és mellhártyagyulladásban meghaltak száma is jelentősen megemelkedett: az azt megelőző tíz év során az e tételnél szereplő 40114 és 46310 között ingadozó halálozási esetszám 87 359-re ugrott. Az ebben a két halálokban meghaltak számának emelkedése teljes egészében magyarázza az összhalálozás számának 384 628-ról (1917) 473 364-re emelkedését 1918-ban [7]. A haláloki struktúra történeti átalakulása során azonban egyre világosabbá vált, hogy az influenzához nemcsak a tüdőgyulladásos halálesetek, hanem a más, légzôszervi vagy cardiovascularis okból bekövetkező halálesetek számának növekedése is kapcsolódhat. Ezért a későbbi elemzések egy része a teljes légzőszervi és cardiovascularis mortalitás növekedését vette alapul az influenzával kapcsolatos többletmortalitás becslésekor.

A másik, e területen elterjedt metódus, az ún. Serflingmódszer a teljes halálozásból indult ki, annak a mérsékelt égövi körülmények között jól ismert naptári év alatt mutatott ciklikusságát alapul véve $[8,9]$. A halálozás általában az év elejétől csökkenő tendenciát mutat, mely csökkenés az év 28-32. hetében újra növekedésnek indul: e periodicitást is láthatjuk a 2015-ös és 2017-es kiugró halálozású éveket is magában foglaló, a magyarországi halálozást heti bontásban bemutató 1 . ábrán.

A modell továbbfejlesztését a különösen magas, illetve alacsony hőmérséklet és a halálozás kapcsolatára vonatkozó ismeretek gyarapodása indokolta. Számos országban tapasztalták, hogy nemcsak a különösen magas hőmérséklet, azaz a hőhullámok, hanem a különösen hideg időjárási periódusok is a halálozás mérhető növekedését hozzák magukkal [10-12]. Az északi féltekén jellemzően a téli hónapokban jelentkező influenza okozta halálozási többletet tehát célszerünek tûnt elválasztani az extrém hideg idő által esetlegesen okozott halálozási többlettől. Erre a problémára kínált megoldást Nielsen, Krause és Mølbak, a heti halálozás alakulását két determináns (az influenzajárvány-aktivitás és az extrém hőmérséklet) függvényében elemezve a FluMOMO-modell segítségével [6].

\section{A FluMOMO-modell}

A modell a halálozások heti számát (mint függó változót), illetve a heti halálozási rátát modellezi egy multiplikatív túlszórásos Poisson-modell segítségével (www. EuroMOMO.eu). Két magyarázó változót léptet be a modellbe: az influenzaaktivitás (IA) és az extrém hőmérséklet (ET) változóját. Az alap- (baseline) modell egy trendkomponenst foglal magában (amely a halálozás évi változását hivatott megjeleníteni), valamint egy (szinuszés koszinuszfüggvények segítségével modellezett) szezonalitási komponenst. Ennek kapcsán a szerzők megjegyzik, hogy a mortalitás változása nem biztos, hogy 


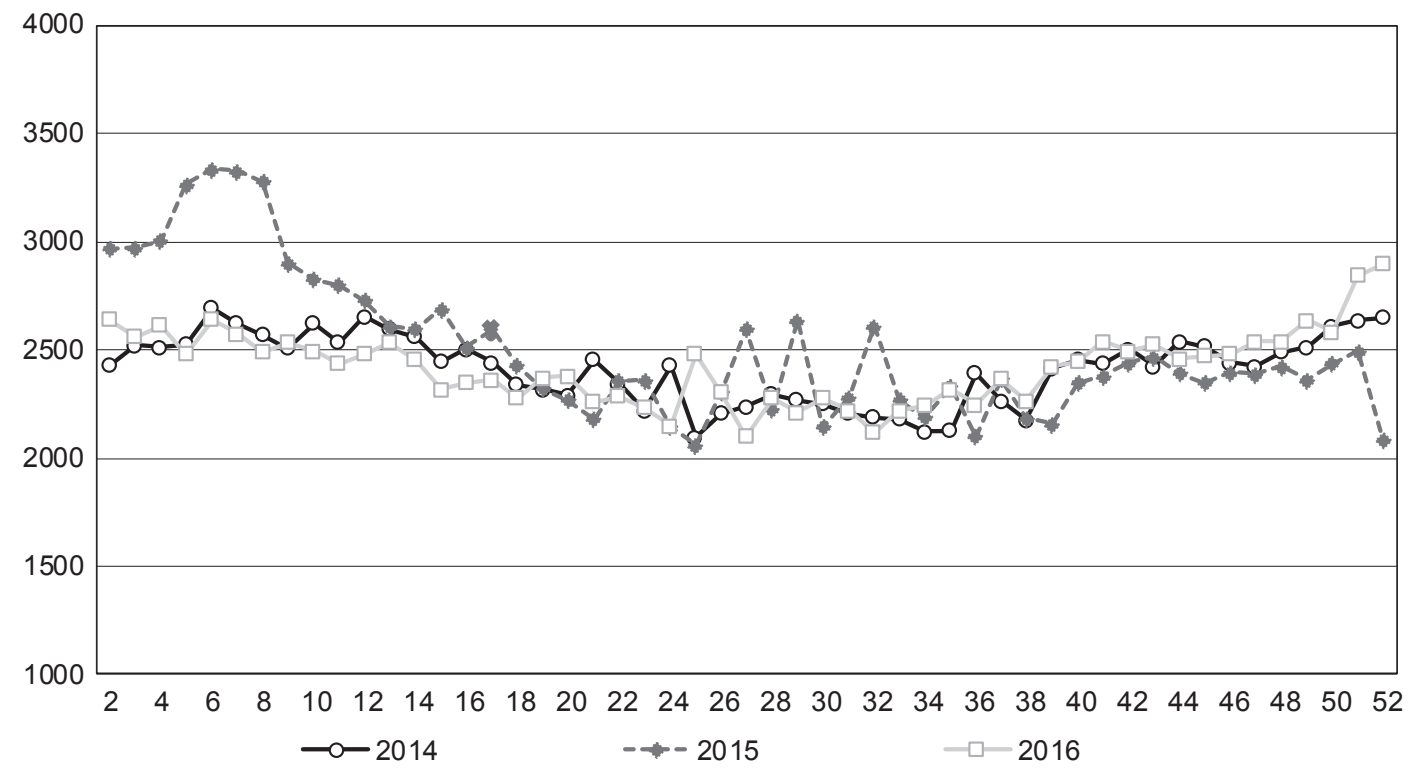

1. ábra \begin{tabular}{|l} 
A halálozások száma hetente Magyarországon, 2014, 2015 és 2016 \\
Forrás: Központi Statisztikai Hivatal
\end{tabular}

hosszabb időszakra nézve helyesen közelíthető lineáris trendkomponens segítségével, így a modell használatát alapvetően 4-5 év hosszú periódusokra ajánlják. A magyarázó változó hatásának vizsgálatát nem korlátozzák azokra az időszakokra, amikor ezeknek az értéke különösen magas (azaz járványidőszakra), hanem - általában kéthetes - elhúzódó ( „lag”) hatásokat is figyelembe vettek. A modell egyszerre becsüli meg az alapmodellt és a magyarázó változók hatásait, végeredményként pedig a többlethalálozás nagyságát nyújtja, halálozási számban, illetve rátában kifejezve.

\section{A modell magyarázó változói}

Az influenzaaktivitást magyarázó változóban az eredeti modell az adott héten az influenzaszerü tünetekkel orvoshoz fordulók arányából (azaz az összes, háziorvoshoz forduló közül az ezt influenzaszerű tünetekkel tevők arányából) indul ki. Az influenzaszerü tünetekkel orvoshoz fordulók számát a háziorvosok „őrszem” (sentinel)-hálójába tartozó orvosok jelentései alapján ismerik Dániában. Magyarországon ugyanezeket az adatokat, ugyancsak a sentinelhálózatba tartozó háziorvosok jelentései alapján, az ÁNTSZ influenzafigyelő szolgálata összegzi. A WHO ajánlásainak megfelelően ezek az adatok Magyarországon 0-4, 5-14, 15-64 és 65+ éves korcsoportos bontásban rendelkezésre állnak. A háziorvosokhoz fordulók heti száma, bár mindkét országban ismert, de nem a fent említett életkori bontásban. Mind Dániában, mind pedig Magyarországon ezért különböző feltételezésekre volt szükség az egyes korcsoportos konzultációs arányok becslésére. Az influenzaaktivitásnak egy másik, szokásosan használt indikátora a beküldött minták közül a pozitívnak bizonyulók aránya. A konzultációs rátát a pozitivitási aránnyal szorozva juthatunk az ún. Goldstein-indexhez. A számunkra kiindulópontként szolgáló tanulmányban mindhárom indexet használták, Magyarországra vonatkozóan azonban csak a konzultációs arány indexét tudtuk használni, mivel a beküldött minták száma egyes heteken nagyon alacsony volt, és csak néhány naptári hétre vonatkozóan haladta meg a százat, s ez a tény komoly bizonytalanságot okozott volna a pozitivitási arány kiszámításakor - ezért ettől eltekintettünk.

Az extrém hőmérsékleti viszonyokat a helyi méróállomások adatainak alapján mindkét országban a „National Oceanic and Atmospheric Administration (NOAA) Online Climate Data Directory" adatai alapján lehetett meghatározni, ehhez a Nielsen és mtsai [6] által kínált programcsomag automatikusan kapcsolódott (FluMOMO 4.1 verziójú $\mathrm{R}$ szoftvercsomag). A heti hőmérsékleti adatok segítségével a várható hőmérsékleti adatoktól való eltérést használtuk az extrém hőmérséklet mutatójaként: a várható minimális hőmérséklet alatti, illetve a várható maximális hőmérséklet feletti értékek adták az „ET” változó nominális értékét (2. ábra).

Magyarországon, ahogy a 2. ábrán is látható, a 2010es év végén, a 2012-es év elején, illetve 2017 elején is voltak különösen hideg periódusok, így az extrém hőmérséklet szerepeltetése a modellben indokoltnak tünik.

A modell használatát annak kidolgozói elsôsorban az éves influenzajárványok gyors értékelésére ajánlják (azokra az időszakokra, amikor a halálozások heti száma már ismert, de az okspecifikus részletes adatok publikálására még nem került sor). Mi ezenfelül a modell alkalmazásának hasznát a nemzetközi összehasonlítás területén látjuk. 


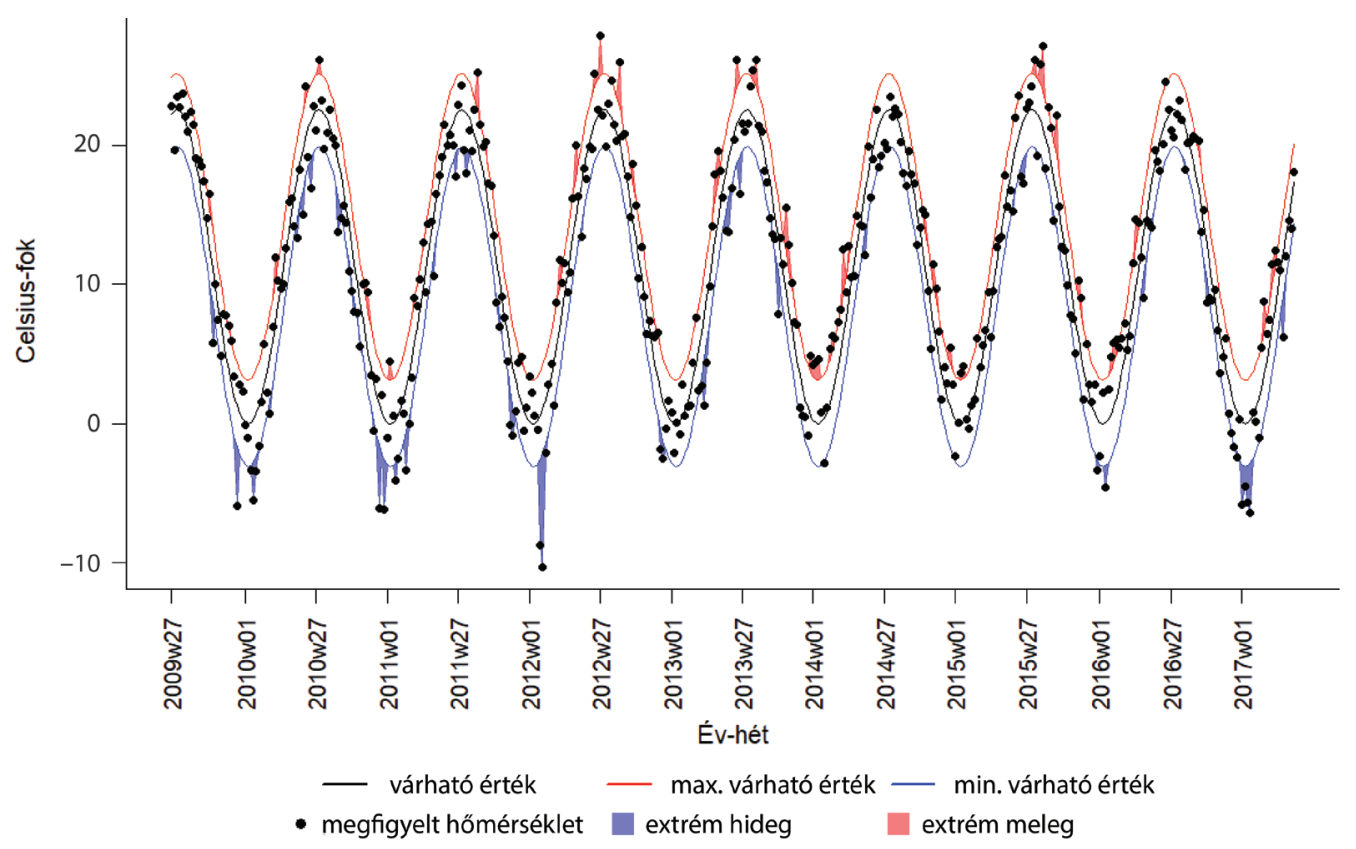

2. ábra | A napi átlaghőmérséklet heti középértékei Magyarországon, 2009/10-2016/17

Az influenza Magyarországon, mint a legtöbb európai országban, változó időpontokban jelenik meg, de a legtöbbször az év első hónapjaiban szedi a legtöbb áldozatot. A járvány nagyon sok esetben azonban már decemberben vagy még korábban megkezdődik, így a továbbiakban a járványügyi terminológiának megfelelöen, „szezonokra” bontjuk az általunk vizsgált időszakot. Az októbertól a következő év áprilisáig tartó szezonhoz kapcsolódó eredményeket azonban eseti jelleggel, leegyszerúsítve, a szezon január és április közötti időszakát magában foglaló naptári évhez kapcsolva is bemutatjuk.

\section{Eredmények}

Ebben a cikkben az extrém időjáráshoz köthető halálozási többletre vonatkozó eredményeket nem, csupán az influenzajárványhoz kapcsolódókat mutatjuk be. Az influenzával kapcsolatba hozható többlethalálozás nagyságára vonatkozó eredményeket a 3. ábra összegzi, a Nielsen és mtsai [6] által Dániára számolt eredményekkel való összevetésben pedig az 1. táblázat és a 4. ábra demonstrálja.

A korcsoportok és a teljes népesség halálozására vonatkozó 3. ábra szerint az influenzához köthető halálozás 2011 januárjában megközelítette a megbízhatósági sáv felső határát, 2012, 2015 és 2017 első hónapjaiban pedig biztosan meghaladta azt, ráadásul 2015 és 2017 első hónapjaiban a túlhalálozás jelentős mértékû volt. Az influenzához köthető halálozás a Dániával való összevetésben - a 2013/2014-es és a 2015/2016-os szezont kivéve - minden évben Magyarországon volt nagyobb.

A népességszámot is figyelembe véve, Dániához képest 2010/2011-ben tízszeres, 2011/2012-ben közel ötszörös, 2014/2015-ben kétszeres, 2016/2017-ben pedig legalább kétszeres halálozást tapasztalhattunk
Magyarországon. A 2013/2014-es szezonban pedig Dániában lényegében nem mutatkozott influenzához kötődő többlethalálozás, míg Magyarországon 1000 közeli volt az áldozatok száma (4. ábra).

1. táblázat $\mid$ Az influenzához köthető halálozások száma Magyarországon és Dániában, ILI (influenzaaktivitás)-alapú becslések, 2009/10$2016 / 17$

\begin{tabular}{|c|c|c|c|c|c|c|}
\hline \multirow[t]{2}{*}{ Szezon } & & \multicolumn{5}{|c|}{ Halálozási esetszám } \\
\hline & $\begin{array}{l}\text { Életkor } \\
\text { Ország }\end{array}$ & $\begin{array}{c}0-4 \\
\text { évesek }\end{array}$ & $\begin{array}{c}5-14 \\
\text { évesek }\end{array}$ & $\begin{array}{l}15-64 \\
\text { évesek }\end{array}$ & $\begin{array}{c}65+ \\
\text { évesek }\end{array}$ & $\begin{array}{c}\text { Össze- } \\
\text { sen }\end{array}$ \\
\hline $2009 / 10$ & Magyarország & 2 & 1 & 604 & 284 & 1091 \\
\hline \multirow{2}{*}{$2010 / 11$} & Magyarország & 22 & 5 & 809 & 2116 & 2969 \\
\hline & Dánia & 7 & 1 & 221 & 166 & 118 \\
\hline \multirow[t]{2}{*}{$2011 / 12$} & Magyarország & 21 & 4 & 420 & 3746 & 4036 \\
\hline & Dánia & 25 & 0 & 245 & 436 & 494 \\
\hline \multirow[t]{2}{*}{$2012 / 13$} & Magyarország & 20 & 0 & 227 & 2367 & 2336 \\
\hline & Dánia & 0 & 0 & 327 & 1736 & 2064 \\
\hline \multirow[t]{2}{*}{$2013 / 14$} & Magyarország & 20 & 8 & 390 & 1912 & 2608 \\
\hline & Dánia & 38 & 0 & 206 & 2 & 2 \\
\hline \multirow[t]{2}{*}{$2014 / 15$} & Magyarország & 5 & 3 & 641 & 5765 & 6470 \\
\hline & Dánia & 14 & 1 & 406 & 1545 & 1861 \\
\hline \multirow[t]{2}{*}{$2015 / 16$} & Magyarország & 7 & 3 & 5 & 54 & 51 \\
\hline & Dánia & 16 & 2 & 193 & 983 & 1004 \\
\hline \multirow[t]{2}{*}{$2016 / 17$} & Magyarország & 1 & 10 & 830 & 4060 & 5162 \\
\hline & Dánia & 20 & 1 & 20 & 1152 & 1231 \\
\hline
\end{tabular}

Magyarázat: A táblázatban szereplő számok becslések, a hozzájuk tartozó megbízhatósági intervallumokat praktikus okokból nem tüntettük fel. A bizonytalanságból adódóan az egyes korcsoportokra vonatkozó becslések összege nem egyezik a teljes népességre vonatkozó becsléssel, mely utóbbi ugyanakkor a legpontosabbnak tekinthető. Az egyes korcsoportokra vonatkozó becslések megbízhatóságát a rátákra vonatkozó 4 . ábra illusztrálja. 


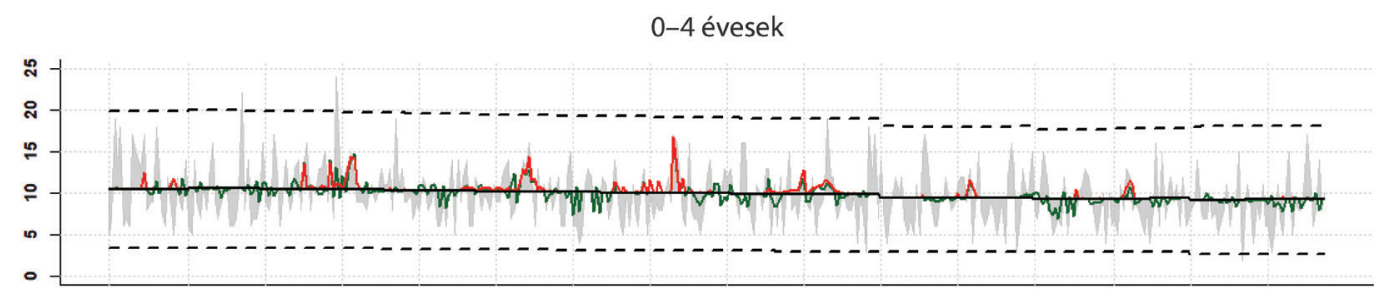

5-14 évesek
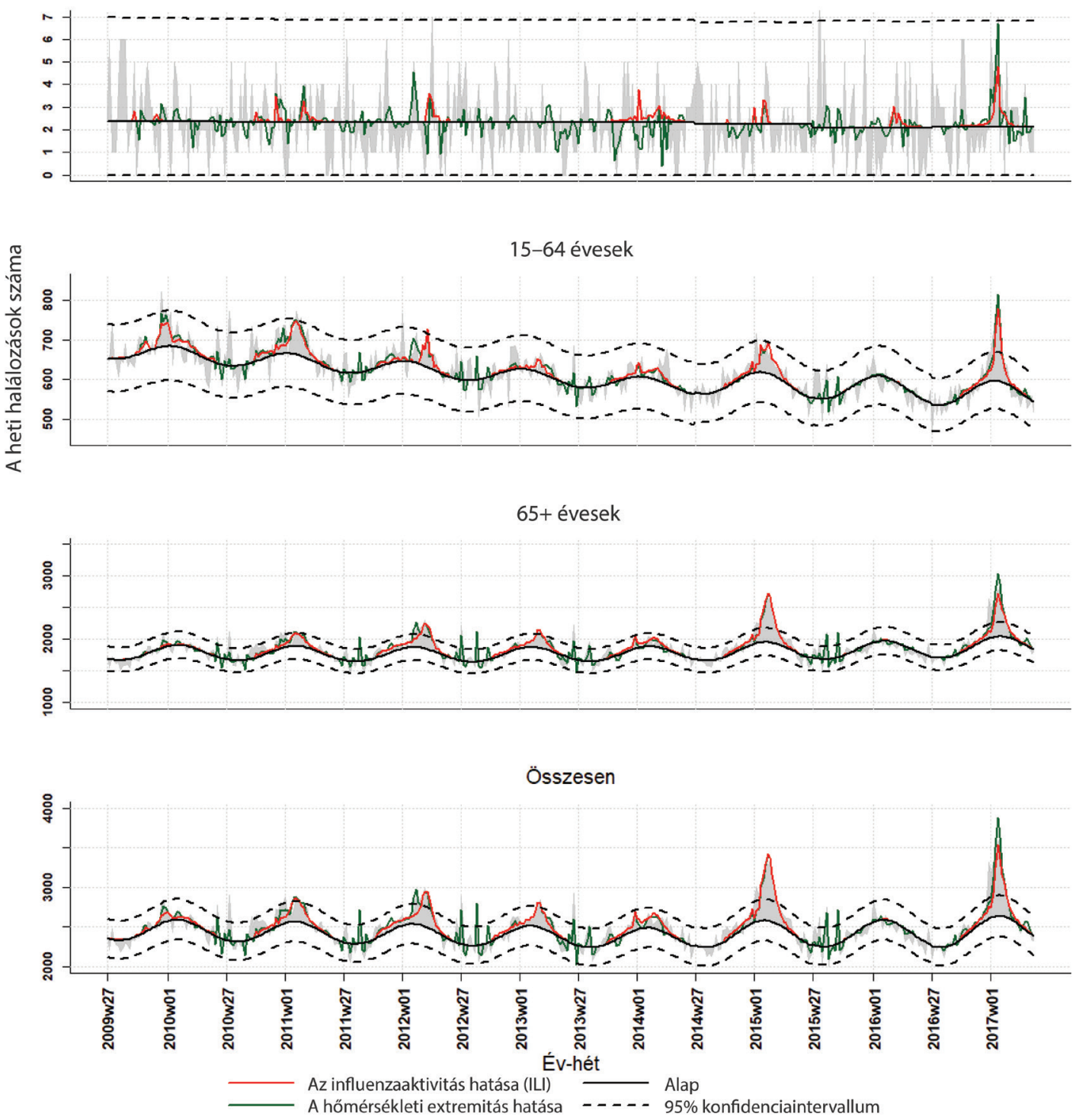

3. ábra | Az influenzához köthető halandóság Magyarországon, 2009/10-2016/17

A 2014/2015-ös szezonra a modell által számolt összes többlethalálozás (5985 fó) Magyarországra nézve nagyon közel áll Wéber András korábban számolt becslésének eredményéhez (5690fó). Ez utóbbi becslés a 2014-es év megfelelő hónapjaiban történt halálozásokhoz hasonlítva számítja ki a 2015-ös többlethalálozást, az adott évek első negyedévében bekövetkezett halálozásokat összevetve [5]. Ebben a kalkulációban az is kimutatható volt, hogy a többlethalálozás nagy arányban érintette a nóket: az 5690 fós halálozási többlet
2047 férfi és 3643 női haláleset összességeként állt elő [5]. Ebben a számításban az 50 éven aluliak körében nem mutatkozott jelentős többlethalálozás. A nők kockázatát elsősorban az 50-59 évesek között találta Wéber magasabbnak, míg a többi korcsoportban a halálozási kockázat növekményei nem tértek el egymástól jelentősen a férfiak és a nók körében. A halálozási többletben tapasztalt női túlsúly így elsôsorban a nőknek az idősebb korosztályokban tapasztalható magasabb arányából adódott. 


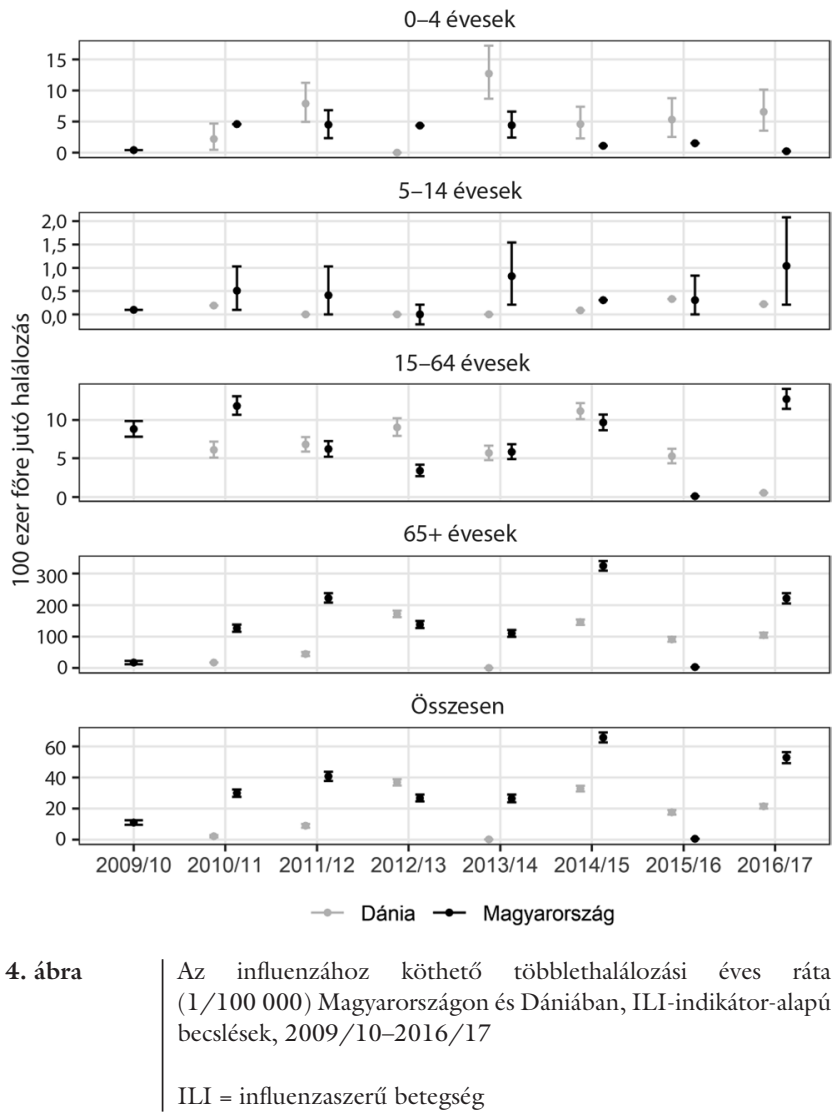

Saját, most bemutatott számításaink szerint az influenza okozta többlethalálozás minden korcsoportban és minden évben megjelent, bár a 0-4 és különösen az 5-14 éves korcsoportban a halálozások száma minden évben alacsony volt. Ugyanakkor a 15-64 éves korcsoportban a halálozások száma a 2015/16-os szezont, azaz a 2016-os év elejét kivéve több százra volt tehető. A 65 éven felüliek korcsoportjában pedig a 2009/10-es és a 2015/16-os szezon kivételével a halálozási szám ezrekben volt mérhetó; részletesen: a 2010/11-es, a 2012/13-as és a 2013/14-es szezonban 2000 körül alakult, 2011/12-ben meghaladta a 3000-et, 2016/17ben 4000-nél, 2014/15-ben pedig 5500-nál is magasabb volt.

A többlethalálozás abszolút számokban mért nagyságát a rátákhoz hasonlóan csak bizonytalansággal tudjuk meghatározni, de a megbízhatósági intervallumokat az abszolút számok esetében (a korábbi, dániai becslésekre vonatkozó publikáció eljárásához igazodva) nem tüntettük fel az 1. táblázatban. Az egyes korcsoportokra kapott becslések így nem mindig adják ki pontosan a teljes népességre kapott becsléseket. A legmegbízhatóbbnak ugyanakkor a teljes népességre vonatkozó becslések tekinthetók.

A teljes népességre vonatkozó eredmények szerint csupán a 2015/16-os szezonra vonatkozóan minősíthető a többlethalálozás mértéke (51 fó) alacsonynak. 2009/10ben 1091, 2010/11-ben 2969, 2011/12-ben 4036, 2012/13-ban 2336, 2013/14-ben 2608, 2014/15-ben
6470, 2016/17-ben pedig 5162 haláleset volt az influenzának tulajdonítható. A szigorúan véve szezonokra számolt, ugyanakkor Magyarországon általában fóképpen január és március között bekövetkező többletesetszámot célszerú a szezon másodikként megjelölt évében történt halálesetek számához viszonyítani. 2010-ben 130 456, 2011-ben 128 795, 2012-ben 129 440, 2013ban 126778,2014 -ben 126 308, 2015-ben 131697 , 2016-ban 127 053, 2017-ben pedig 131700 haláleset történt. A két adatsor egybevetése alapján jól látható, hogy a most számított többlethalálozás éves szinten is jelentős mértékú, valamint hogy az influenza okozta halálozás nagy valószínúséggel szerepet játszott abban, hogy a halálozások éves számában mutatkozó csökkenő tendencia a legutóbbi években megtörni látszik.

\section{Megbeszélés}

Mindeddig két további, olyan részletes, országspecifikus elemzést tettek közzé, amely a dán kutatók által kidolgozott modell segítségével készült. Angliára nézve a 2008/09 és 2014/15 közötti évekre vonatkozóan határozták meg a kutatók az influenzához köthető halálozás nagyságát [13]. Az ILI-indikátor használatával kapott becsléseiket számszerúen csak az egyes korcsoportokra külön adták meg. Mint ahogyan várható volt, a legnagyobb többlethalálozási esetszámok Angliában is a 65+ évesek körében jelentek meg: 14261 (2008/09-ben), 471 (2009/10-ben), 2428 (2010/11-ben), 3625 (2011/12-ben) [13], 7792 (2012/13-ban), (2013/14ben), illetve 26542 (2014/15-ben). Az esetszámok talán magasnak tûnnek, ugyanakkor Anglia 65+ éves népességéhez viszonyítva a 2014/15-ös kiugró halálozási szám is alacsonyabb halálozási rátát $(273 / 100000)$ eredményezett, mint az az évi magyarországi (351/100 000), de magasabbat mint a dániai $(111 / 100000)$. A magas (71\% feletti) oltási aránnyal rendelkező Egyesült Királyságban a 2014/15-ös év tehát szintén kiugró halálozást hozott, amelynek szintje azonban mérsékeltebbnek bizonyult, mint az alacsony oltási aránnyal rendelkező Magyarország rátája. Ebben a kitüntetett szezonban a magas halálozást a kutatók az A(H3N2)-vírus dominanciájának tulajdonították, amelyhez az az évi oltás kevéssé illeszkedett.

Az Olaszországra vonatkozó elemzés [14] a 2013/14 és 2016/17 közötti időszakra vonatkozik, és mind az ILI-indikátor, mind pedig a Goldstein-index segítségével kapott többlethalálozási becsléseit közzéteszi. Fontos megjegyezni, hogy a Goldstein-index segítségével kapott becslések rendre jóval alacsonyabbak, amire egyelöre nincs magyarázat. Az ILI-indikátor segítségével kapott becslések szerint az influenzának tulajdonítható halálesetek száma összesen 24000 és 43000 között alakult. Az olaszországi becslések ráták formájában is rendelkezésre állnak: a teljes népességre vonatkozó ráták 40 és 70 százezrelék között alakultak (különösen magas értéket véve fel a 2014/15-ös és a 2016/17-es szezonban). Az erős 
járványos évekre kapott olaszországi eredmények nagyságrendje nagyon közel áll a magyarországi súlyosabb járványos évekre kapott eredményekhez: ez a magyarországi népességre nézve 65,37 százezrelék volt 2014/15ben és 52,72 százezrelék 2016/17-ben. A teljes népességre vonatkozó rátáknak azonban - a hasonló, részletes korcsoportos mortalitási ráták alapján - a jóval idősebb olaszországi népességben magasabb szinten kellett volna alakulniuk a fiatalabb magyarországi népességben tapasztalthoz képest. Az olaszországi hasonló „nyers” ráták tehát a magyarnál alacsonyabb halálozásra utalnak, magasabb vakcinációs ráta $(48 \%$ 2015-ben) mellett.

A Magyarországra vonatkozó lehetséges összehasonlítható eredményeket keresve, egyszerúbb módszerekkel készült elemzésre kell hagyatkoznunk. A járványmentes és a járványos években tapasztalt halálozási számok öszszevetése, mint fentebb bemutattuk, valójában igen jó becslést ad az influenzához kötődő többlethalálozás nagyságára. Érdemes ezért a korábbi, hasonlóan egyszerü módszerekkel készült becslések eredményeire is kitérni. Mádai [15] az 1971-es és 1972-es évek halálozási adatait összehasonlítva 5878 halálesetet tulajdonít az 1971-es járványnak. Ez a becslés tehát nagyságrendileg megegyezik a 2010-es évek során jelentkezett éves halálozási többletek közül a magasabb értékekkel. Ebből azonban nyilvánvalóan nem az a következtetés vonandó le, hogy az influenza elleni védekezés szintje az 50 évvel ezelőtti szinten állna. Magyarázatként felmerülhet, hogy az influenzajárványok aktivitása, mortalitásra gyakorolt hatása az utóbbi években növekedett. Erre utal például holland kutatók megfigyelése az ILI-indikátor segítségével mért influenzaaktivitásnak az 1970 és 2000 közötti csökkenéséről, majd 2000-et követő növekedéséről [16]. Más típusú megfontolások alapján több közegészségügyi szakértő is úgy véli, hogy a jövőben az influenza növekvő számú megbetegedéssel és halálozással jár majd együtt [4], következésképpen az influenza elleni védekezésnek is intenzívebbé kell válnia.

$\mathrm{Az}$ influenza elleni védekezésnek ma ismert egyetlen módszere a vakcináció. A Magyarországon számításaink szerint tapasztalt, influenzához kötődő - Dániához viszonyítva szisztematikusan magasabb - többlethalálozás magyarázatát természetes módon a vakcináció helyzetében kereshetjük, hiszen ismert, hogy Magyarországon az ajánlottnál jóval kevesebb vakcináció történik [17]. A vakcinációs helyzet azonban nehezen értékelhető pontosan, hiszen nemzetközileg összehasonlítható adatok csak a 65+ évesek vakcinációjára nézve állnak rendelkezésre. Az OECD adatai alapján Magyarországon 2002ben - legalábbis a $65+$ évesek körében - a vakcinációs ráta még 40\% körül volt, amely azonban már a következő években is enyhén csökkenő tendenciát mutatott, 2009-et követően pedig erőteljesen csökkent, 2015-re a 20\%-os érték felé közelítve (5. ábra).

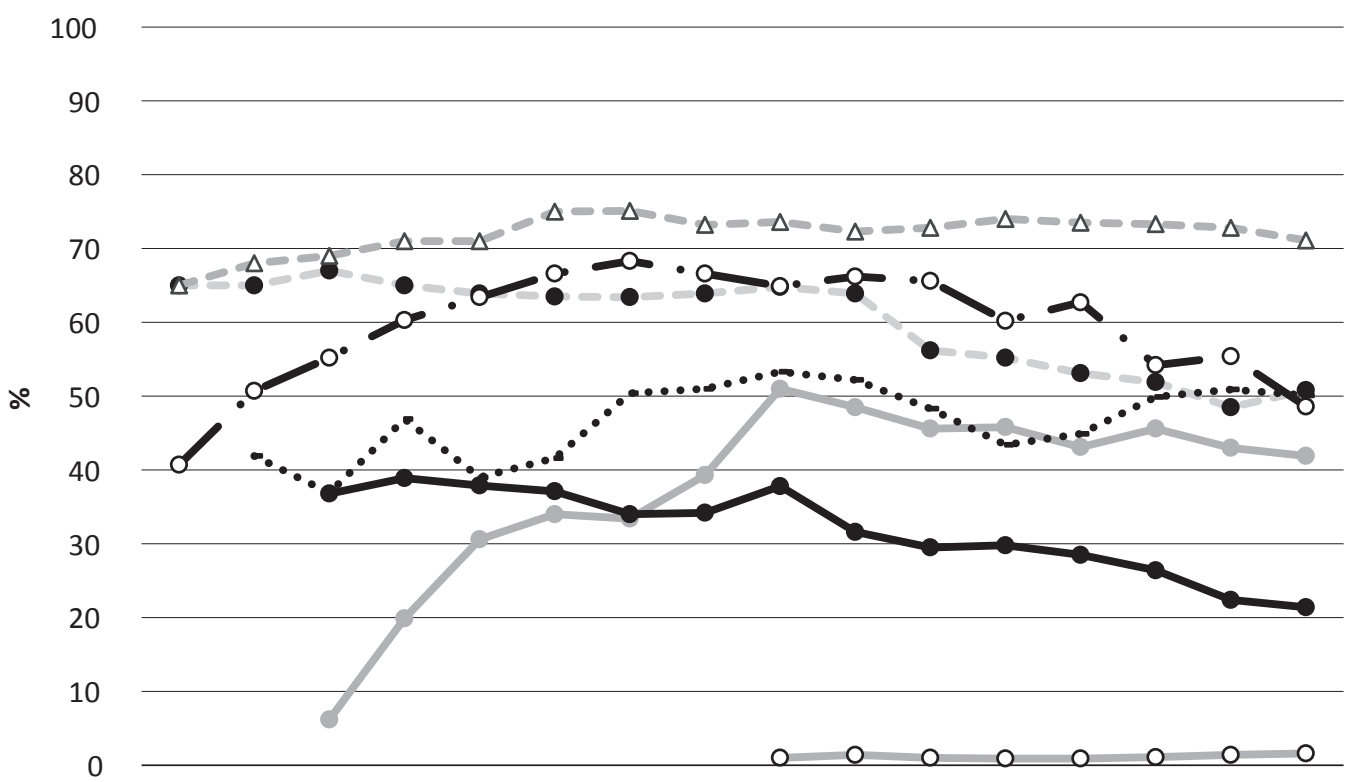

2000200120022003200420052006200720082009201020112012201320142015
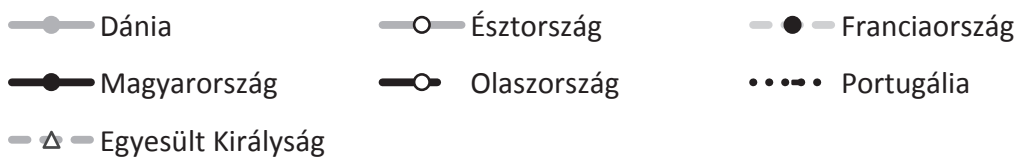

$-\Delta-$ Egyesült Királyság

\begin{tabular}{l|l} 
5. ábra & $\begin{array}{l}\text { A vakcinációs ráta Európa egyes országaiban, a } 65 \text { éven felüli népesség körében (\%) } \\
\text { Forrás: Gazdasági Együttmúködési és Fejlesztési Szervezet }\end{array}$
\end{tabular} 
A 2009-es évet, amely a vakcinációval kapcsolatos bizalom megingását hozta magával, számos országban az oltási kedv mérséklődése követte, mint ahogyan az 5. ábrán látható. Ezt követően azonban egyes országokban (ábránkon Portugália) az oltások iránti bizalom újra erősödni kezdett, más országokban pedig (ábránkon az Egyesült Királyság) az oltási ráta mindvégig magas maradt. Az 5. ábrán csak európai országokat szerepeltetünk, ugyanakkor az OECD adatai alapján a magasabb jövedelmú ázsiai országokban ma az oltási arányok jóval magasabbak, mint az európaiak, sőt az utóbbi években számos dél-amerikai ország, város is kiemelkedő vakcinációs arányt ért el, jelentősen mérsékelve az influenza által okozott károkat.

Az influenzaoltásokkal kapcsolatos bizalmatlanság többféle forrásból származik. Való igaz, hogy az oltásoknak a WHO által meghatározott összetétele nem mindig bizonyult optimálisnak [18]. A jól eltalált összetételú vakcinák ugyanakkor bizonyíthatóan csökkentik mind a morbiditást, mind pedig a mortalitást. Az influenzával kapcsolatban ritkák a követéses vizsgálatok, az egyik ilyen kivételesen kiterjedt és igényesen kivitelezett skóciai vizsgálat elsősorban a mortalitás és a hospitalizáció csökkenésében mutatta ki a vakcináció hatását [19]. Mindemellett a vakcináció gazdasági szempontból is kifizetődő: a morbiditás csökkentése kapcsán jelentősen mérsékli a megbetegedésekhez kapcsolódó termeléskiesést $[20,21]$.

Az influenzával és a vakcinával kapcsolatos attitűdök döntő szerepet játszanak a betegséggel kapcsolatos védekezésben. Nemzetközi tapasztalatok alapján ismert, hogy a különböző országokban a vakcinációval kapcsolatos ellenérzések meglepően hasonlóak: az oltásoktól való félelem általában, a tûtő́l való félelem, az a meggyőződés, hogy egészséges embert az influenza nem támad meg, és az a meggyőződés, hogy a vakcina nem hatásos, minden országban felbukkan $[22,23]$. A professzionális közösség csupán arányaiban vall ettől különböző nézeteket. A legutóbbi években végzett kérdőíves vizsgálatok alapján Magyarországon az alapellátásban dolgozó orvosoknak csupán a kétharmada volt - általában - a védőoltások meggyőződéses híve. Hasonlóan, az orvostanhallgatók közel egyötöde még a témára vonatkozó célzott oktatás után sem mutatott bizalmat az influenzaoltással kapcsolatban. A vakcináció előnyeiről folyó diskurzus intenzívebbé tétele, az esetleges alternatív védekezési módszerek hatásainak megvitatása segítene az influenza negatív hatásainak csökkentésében. Tudatosítani kellene, hogy mely csoportok különösen veszélyeztetettek, milyen a fertőzés terjedésének dinamikája, és ehhez kapcsolódóan kellene kialakítani az optimális vakcinációs stratégiát. Amennyiben a társadalom és az orvostársadalom is a vakcináció növelése mellett dönt, az attitűdök formálása mellett az oltáshoz való hozzájutás megkönnyítése is cél lehet.

A közeljövőben feltehetően nagyságrendileg jobb védelmet kínáló vakcinák előnyeit csak egy olyan társada- lom tudja kamatoztatni, amelyben a vakcinációval kapcsolatos hozzáállás támogató jellegü, és ez feltehetően sokat segíthetne az influenzával kapcsolatos halálozás mérséklésében, ezenfelül a teljes mortalitás javulásában, hiszen a jelen tanulmányban nem szereplő 2018-as és 2019-es év első három hónapjában ismereteink szerint a 2015-ös évhez hasonló halálozási csúcs mutatkozott hazánkban.

Anyagi támogatás: A kutatómunka és a cikk megírása anyagi támogatásban nem részesült.

Szerzői munkamegosztás: K. K.: A kutatás alapjául szolgáló adatok összegyưjjtése, az eredmények összesítése, a kézirat megszövegezése. P. L.: Az adatok statisztikai elemzése. A cikk végleges változatát mindkét szerző elolvasta és jóváhagyta.

Érdekeltségek: A szerzőknek nincsenek érdekeltségeik.

\section{Irodalom}

[1] Beiner G. Out in the cold and back: new-found interest in the great flu. Cult Social History 2006; 3: 496-505

[2] Joshnson NP, Mueller J. Updating the accounts: global mortality of the 1918-1920 "Spanish" influenza pandemic. Bull Hist Med. 2002; 76: 105-115.

[3] Bengtsson T, Dribe M, Eriksson B. Social class and excess mortality in Sweden during the 1918 influenza pandemic. Am J Epidemiol. 2018; 187: 2568-2576.

[4] Voelker R. Vulnerability to pandemic flu could be greater today than a century ago. JAMA 2018; 320: 1523-1525.

[5] Wéber A. Preliminary investigation of excess mortality in the first quarter of 2015. Manuscript. [Előzetes áttekintés a 2015 első negyedévében tapasztalható halálozási többletról. Kézirat.] Központi Statisztikai Hivatal, Budapest, 2016. [Hungarian]

[6] Nielsen J, Krause TG, Mølbak K. Influenza-associated mortality determined from all-cause mortality, Denmark 2010/112016/17: the FluMOMO model. Influenza Other Respir Viruses $2018 ; 12$ : 591-604.

[7] Hungarian Central Statistical Office. Demographic yearbook 2010. [Központi Statisztikai Hivatal. Demográfiai évkönyv 2010.] KSH, Budapest, 2010. [Hungarian]

[8] Serfling RE. Methods for current statistical analysis of excess pneumonia-influenza deaths. Public Health Rep. 1963; 78: 494506.

[9] Thompson WW, Weintraub E, Dhankhar P, et al. Estimates of US influenza-associated deaths made using four different methods. Influenza Other Respir Viruses 2009; 3: 37-49.

[10] Anderson BG, Bell ML. Weather-related mortality: how heat, cold, and heat waves affect mortality in the United States. Epidemiology 2009; 20: 205-213.

[11] Huynen MM, Martens P, Schram D, at al. The impact of heat waves and cold spells on mortality rates in the Dutch population. Environ Health Perspect. 2001; 109: 463-470.

[12] Hajat S, Kovats RS, Lachowycz K. Heat-related and cold-related deaths in England and Wales: who is at risk? Occup Environ Med. 2007; 64: 93-100.

[13] Pebody RG, Green HK, Warburton F, et al. Significant spike in excess mortality in England in winter 2014/15 - influenza the likely culprit. Epidemiol Infect. 2018; 146: 1106-1113.

[14] Rosano A, Bella A, Gesualdo F, et al. Investigating the impact of influenza on excess mortality in all ages in Italy during recent 
seasons (2013/14-2016/17 seasons). Int J Infect Dis. 2019; 88: $127-134$

[15] Mádai L. Impact of influenza epidemics on mortality in Hungary. [Influenzajárványok hatása a halandóságra.] Demográfia 1973; 16: 336-344. [Hungarian]

[16] Caini S, Spreeuwenberg P, Donker G, et al. Climatic factors and long-term trends of influenza-like illness rates in The Netherlands, 1970-2016. Environ Res. 2018; 167: 307-313.

[17] Sándor J, Czifra Á. Effectiveness of preventive service delivery in primary health care for adults: nationwide Hungarian survey 2014. [A felnőtteket ellátó háziorvosok által végzett kardiometabolikus rizikófaktorszưrés és influenza elleni vakcinálás hatékonysága Magyarországon 2014-ben.] Demográfia 2018; 61: 147-190. [Hungarian]

[18] Paules CI, Fauci AS. Influenza vaccines: good, but we can do better. J Infect Dis. 2019; 219(Suppl 1): S1-S4.

[19] Corson S, Robertson C, Reynolds A, et al. Modelling the population effectiveness of the national seasonal influenza vaccination programme in Scotland: the impact of targeting all individuals aged 65 years and over. Influenza Other Respir Viruses 2019; 13: 354-363.
[20] Baguelin M, Jit M, Miller E, et al. Health and economic impact of the seasonal influenza vaccination programme in England. Vaccine 2012; 30: 3459-3462.

[21] Kovács G, Kaló Z, Jahnz-Rozyk K, et al. Medical and economic burden of influenza in the elderly population in central and eastern European countries. Hum Vaccin Immunother. 2014; 10: 428-440.

[22] Yeung MP, Lam FL, Coker R. Factors associated with the uptake of seasonal influenza vaccination in adults: a systematic review. J Public Health 2016; 38: 746-753.

[23] Schmid P, Rauber D, Betsch C, et al. Barriers of influenza vaccination intention and behavior - a systematic review of influenza vaccine hesitancy, 2005-2016. PLoS ONE 2017; 12: e0170550.

(Kovács Katalin, Budapest, Buday László u. 1-3.; 1024 e-mail: kovacs@demografia.hu)

\section{"Mala mors necessitatis contumelia est." (A rossz halál megszégyenítés a sorstól.)}

A cikk a Creative Commons Attribution 4.0 International License (https://creativecommons.org/licenses/by/4.0/) feltételei szerint publikált Open Access közlemény, melynek szellemében a cikk bármilyen médiumban szabadon felhasználható, megosztható és újraközölhetö, feltéve, hogy az eredeti szerző és a közlés helye, illetve a CC License linkje és az esetlegesen végrehajtott módosítások feltüntetésre kerülnek. (SID_1) 